\title{
THE CIRCUMSTANCE THAT NEEDS TO BE CONSIDERED BY JUDGES OF INDUSTRIAL RELATION COURT IN DECIDING REINSTATE DECISION
}

\author{
Budi Santoso \\ Faculty of Law, University of Brawijaya \\ E-mail: budi.santoso@ub.ac.id
}

\begin{abstract}
The implementation of the Industrial Relations Court verdict in the case of termination disputes which order employers to reinstate workers faces obstacles occasionally. This is caused by the reluctance of employers to comply with the verdict. This article aims to analyze the considered situations that the Industrial Relations Court needs to take into account in declaring a reinstatement decision in the case of termination disputes. Through the use of normative legal research methods with statutory, case, and conceptual approaches, it is concluded that such considerations include: the reinstatement of worker to his/her former job title is not appropriate if the position left by the worker has been filled by another worker; the reinstatement of worker is not appropriately provided if it may cause an unharmonious relationship between employers and workers; the reinstatement of worker is not appropriately provided if it causes prejudice to the worker; the reinstatement of worker is unsuitable if it will have a negative impact on the relationship between the worker and the other workers in the workplace; and/or the reinstatement of worker would be unsuitable if the worker has a confidentiality capacity for the company's secrets because the employer no longer trusts the worker.
\end{abstract}

Keywords: Reinstatement, termination, industrial dispute settlement

\section{A. INTRODUCTION}

Termination of employment can take place on the initiative of a worker/laborer or an employer's initiative. One example of termination of employment carried out at the initiative of workers/laborers is workers/laborers resign on their own accord. While the example of termination of employment at the initiative of the employer is termination that occurs because the company undergoes a merger thus the workers/ laborers are not willing to continue working relationship. Another example is the workers/laborers terminated the employment because they violate the disciplinary provision in company regulations. In particular for termination of employment at the initiative of the employer, Article 152 of Law Number 13 of 2003 on Manpower stipulates that any plan for termination of employment at the initiative of the employer must be negotiated with labor unions/workers/laborers if the workers/laborers concerned are not members of trade unions/labor unions.

$494 \quad$ Yustisia Vol. 7 No. 3 Sept.-Des. $2018 \quad$ TheCircumstanceThatNeedsToBe...

(C)2018; This is an Open Acces Research distributed under the term of the Creative Commons Attribution Licencee (https://Creativecommons.org/licences/by/4.0), which permits unrestricted use, distribution, and reproduction in any medium, provided the original works is properly cited. 
However, in various cases, negotiations on termination of employment are frequently unresolved. This is caused by the eagerness of each party still insisting in its position, where the employer still insist to terminate the employment and workers/ laborers still insist to continue working relationship, or the amount of compensation for termination of employment offered by employer does not properly meet with expectations workers/laborers. The failed termination of employment at the bipartite level is then brought to the settlement mechanism by involving a third party, namely the mediator or conciliator. According to the provisions of Article 5 of Law Number 2 of 2004 on Industrial Relations Disputes Settlement, "In cases where an attempt at settlement through conciliation or mediation does not result in agreement, then one of the parties can file a legal petition to the Industrial Relations Court." The lawsuit file should be submitted to the Industrial Relations Court whose jurisdiction covers the place where the worker/laborer works.

After proceeding of case review in the trial, The Council of Judges takes into consideration the laws, existing agreements, customs and justice in passing the verdict (Article 100 of Law No. 2 of 2004). The verdict of the Council of Judges is read out in the court session, which is open for public. According to Article 101 paragraph (4) Law No. 2 of 2004, Non-compliance of the stipulation as meant of read the verdict in the court session and open to public causes that the Court verdict is not legal and has no legal power.

In the case of a termination dispute proposed by the employer, the judge's decision the form of granting the employer's claim and stating the employment relationship between the employer and the worker/laborer is broken and requires the employer to pay a certain amount of compensation. For example, in the case of a termination dispute between Theresia Adiwijaya (worker) against PT Bank Commonwealth (Supreme Court Decision No. 051 PK/Pdt.Sus/2009), the Court decided that the employment relationship between workers and employers broke up since 28 July 2008 and punished the employer to pay to workers in the form of: severance pay; money for treatment, care and housing; furlough compensation; and the remaining unpaid wages. The total of amount is Rp.2,170,588,500.

Otherwise, the decision of a judge may not grant the employer's claim to terminate employment relations with workers/laborers and punish the employer for reinstating the workers/laborers concerned. This could be decided if the step of terminating the employment is not valid, for example, not accordance with Article 168 of Law No. 13 of 2003 which stipulates that worker/laborer who is absent 5 (five) or more consecutive work days without a doctor's written explanation that includes legal proof and has been summoned properly by the employer 2 (two) times in writing can terminate his/her employment because he/she is qualified to resign (Article 170). 
However, there are a circumstances that the judge's decision to reinstate workers/ laborers is difficult to implement. For example, in a termination of employment dispute between Setyawati (Worker) against PT Belgindo Raya (Employer) in Semarang (Decision of the Industrial Relations Court of Semarang No.33/G/2009/ PHI.SMG), the council of judges decided that employment was terminated by the employer in 3 December 2008 was invalid and the employer was convicted to reinstate worker in the previous position. At the cassation proceeding, the Supreme Court strengthened the decision by stating that Judex Facti did not misuse the law (Supreme Court Decision No. 701 K/Pdt.Sus/2009). However, the decision was not carried out by the employer. In other case, the Supreme Court in examining request of a case review for termination of employment dispute between PT Pertamina and 162 workers with the status of a specific time worker decided that the workers had to be reinstated and their status changed to unspecified time workers (Decision PK No. 13 PK/PHI/2007). However, the decision was never carried out by PT Pertamina (Hukum Online,http://www.hukumonline.com/berita/baca/hol18689/putusanmahkamah-agung-membuat-karyawan-pertamina-bingung) .

The circumstances above occurs naturally considering that the work relationship is basically a relationship of mutual trust and mutual cooperation on the basis of economic interests (Richard N. Block et al., 2004: 94), therefore the psychological relationship that has "broken up" will tend difficult to continue. Employer may become reluctant to reinstate workers/laborers because employer have no longer trusted the workers/laborers or the employer is unwilling to reinstate the workers/ laborers under the reasons of efficiency to maintain the continuity of the company.

\section{B. PROBLEM STATEMENTS}

Based on the background described, this study aims to analyze the circumstances of the Industrial Relations Court judges that needs to consider in making decisions to reinstate the worker/laborer in cases of termination of employment.

\section{RESEARCH METHODS}

In addressing the issue, this study uses a statute approach by analyzing all regulations relating to the issue of decisions being reinstated in cases of termination of employment. The legislation includes: Article 27 paragraph (2) and Article 28D paragraph (2) of the 1945 Constitution of the Republic of Indonesia; Law Number 13 of 2003 on Manpower; Law Number 2 of 2004 on Settlement of Industrial Relations Disputes; Law Number 48 of 2009 on Judicial Power; and the Civil Procedure Code (HIR and RBg). In addition to the statute approach, case approaches and conceptual approaches are also used. The case approach is conducted by analyzing the ratio 
decidendi or judgment of the judge to make a decision that decide to reinstate worker/laborer. Some of these decisions include the Supreme Court Decision No. 701 K/Pdt.Sus/2009 and Supreme Court Decision No. 13 PK/PHI/2007. Meanwhile, the conceptual approach is conducted by analyzing the concept of work relations as a cooperation based on mutual trust in work. The analysis uses teleological interpretation methods.

\section{RESEARCH RESULTS AND DISCUSSION}

Every worker/laborer does not want to lose a job. Losing a job means losing income for the needs of life and family. Therefore, the termination of employment is really being avoided by workers/laborers in general. However, termination of employment is actually a possible and reasonable. (Edi Sutrisno, 2007: 1). Shortly, termination of employment relationship is a logical consequence of working relationship, which possibly caused by indiscipline worker/laborer, inability to work, and company operations.

Therefore, before discussing the conditions that need to be considered by the judge in making a decision to reinstate worker/laborer due to the difficulty of the decision implementation in this section, two related principles will be addressed, i.e. termination of employment by the employer as the last step and workers/laborers have the right to be reinstated if termination of employment is proven invalid.

\section{Termination Of Employment Is Accomplished As The Last Step}

Termination of employment is included as an issue in resolving industrial relations disputes. It examines under the definition of industrial relations disputes as formulated in Article 1 number 1 of Law No. 2 of 2004 "An Industrial Relations Dispute is a difference of opinion resulting in a dispute between employers or an association of employers with workers/laborers or trade unions due to a disagreement on rights, conflicting interests, a dispute over termination of employment, or a dispute among trade unions within one company."

Based on the causes, termination of employment is divided into four types (Adrian Sutedi, 2009: 66):

1) Termination of employment which occurs because of the eagerness of the employer with certain reasons, requirements and procedures;

2) Termination of employment at the initiative of workers/laborers which occurs because their own will;

3) Termination of employment by law that occurs under no necessary action, such as occurs automatically due to the expiration of the the working relationship or because of the death of the worker/laborer; and 
4) Termination of employment by the court (termination of employment by the court especially industrial relations court) which occurs for certain reasons that are urgent and important, for example a transfer of ownership or bankruptcy.

Although termination of employment is the employer's right, Article 151 of Law No. 13 of 2003 regulates that an employer, worker/laborer, workers'/ laborers' union and the government, with every effort must manage so that a termination of employment doesn't occur. The provision clearly stipulates that termination of employment is the last method to save the company. Some examples of actions or ways that employers can do to avoid termination of employment occur, such as by saving operational costs, managing work time, reducing overtime work, improving work methods, and conducting training for workers. If these methods have been carried out, but termination of employment is inevitable, then the employer's decision to terminate employment must be negotiated with a workers'/laborers' union/labor union or with workers/laborers if the workers/laborers are not members of a trade union/union laborer. Such negotiations is able or unable to produce an agreement regarding termination of employment. However, employers are only allowed to terminate employment after obtaining a determination from the industrial relations court.

Based on the description under the provisions of Article 151 of Law No. 13 of 2003 above, it can be concluded that termination of employment is the last step after various alternative ways to avoid it and employers' decisions regarding termination of employment must be discussed with workers/laborers or workers'/ laborers' unions before being submitted to the industrial relations court if the negotiation doesn't result in an agreement.

Even though the employer has the right to terminate employment relations, however as the objective of labor law is to protect workers/laborers due to an imbalance bargaining position of workers/employers to achieve (Lalu Husni, 2008: 11), work rights are interpreted as the right of workers/laborers to feel peaceful and comfortable in their work that should obtain protection through regulations which aimed to prevent termination of employment (Bob Hepple, 1986: 180). Meanwhile, according to Article 153 of Law No. 13 of 2003, the right of employers to terminate employment relations with workers/laborers has been limited, such as through a prohibition arrangement for employers that they do not use certain reasons to break employment relations, i.e : married workers/laborers; sick workers who do not exceed one year; workers fulfill obligations towards the state; workers carry out their religious services; pregnant, miscarriage, childbirth, or breastfeeding women workers; workers have family or marital relations with other workers/laborers in one company; workers establish, become members/ 
administrators, or are active in the activities of worker /labor unions; difference of religion; etc. If the reason is used by the employer to carry out termination of employment, the termination is null and void by law and the worker/laborer must be reinstated.

The restrictions in the form of these prohibitions are an embodiment of the fundamental principles of the ILO as set out in the ILO Declaration on the Objective and Purpose of the International Labor Organization in 1944 that "labor is not a commodity". This indicates the existence of legal protection for workers/laborers that employers do not arbitrarily or will do termination of employment because workers/laborers are not commodity goods such as goods that are easily traded.

\section{Workers/Laborers Have The Right To Be Reinstated If Termination Of Employment Is Not Valid}

The provisions examined in the ILO Declaration and Labor Law above have confirmed that workers have the right to be treated fairly in the practice of termination of employment by employers, both substantively and procedurally. Fair substantively refers to reasons that are justified and proper, while fair procedure is that workers/laborers are given the opportunity to answer and defend themselves on termination of employment on his/herself (Dau-Schmidt et. Al, 2009: 69).

The principle to obtain fair treatment in the practice of terminating employment is a principle related efforts to guarantee employment. This principle was formed following the industrial revolution which had a negative impact on labor practices. At that time, the freedom of contract principle had no limitation. Employers can at any time and at their own discretion to terminate employment relations with workers/laborers. Clearly, this situation has opened the eyes of many countries that the freedom of contract principle must be limited. According to Hepple, the main reason that freedom to contract must be limited is the bargaining power position of workers/laborers were weak compared to employers (Bob Hepple, 1986: 6).

The weak position of workers/laborers generally begins to arise when work agreements are made with employers. Basically, in the making of agreement, the party must always pay attention to the principle of fair balance. However, the balance of the parties in making work agreements will certainly be difficult to materialize due to the position of workers who are weak (Budi Santoso and Ratih Dheviana, 2012: 206). Therefore, government intervention is necessary to provide protection to workers/laborers against opportunities for abuse of the employer's strong position, including protection from efforts to arbitrarily 
terminate employment. The government interference can be in the form of drafting legislation.

Substantive reasons raised by employers to terminate employment relations with workers/laborers must also fulfill procedural justice, for example workers/ laborers must be given the opportunity to defend themselves. Termination of employment by employer who does not fulfill substance justice or procedural justice can be categorized as illegal employment termination and the worker/ laborer has the right to be reinstated by the employer.

For example, in a termination dispute between Setyawati (Worker) against PT Belgindo Raya (Employer) in Semarang (Decision of the Industrial Relations Court Semarang No.33/G/2009/PHI.SMG), workers sued employers that termination of employment by employers is illegal and workers request to be reinstated. The worker argued that the termination of employment by the employer under the reason that the employment contract had expired was against the law. Worker had worked for employers from 27 May 2004 to 2 December 2008 which counted 4 years 7 months with a Specific Time Work Agreement had been made 4 times. According to worker, this action is not in accordance with Article 59 of Law No. 13 of 2003 and by law the employment status of an the worker is a permanent worker so that the worker cannot be terminated under the reason that the contract has expired.

Another example is in case Number 116/G/2008/PHI.SMG, the plaintiffs consisting of Endang, Purnomowati, Kisti Hestining, Suparmi, and Kasmonah which was worked on the CV. Rekafurindo (Employer) addresses at the Terboyo Industrial Estate in the East Jakarta Terboyo Road Block E No.12, Genuk District, Semarang City sued the employerr at the Industrial Relations Court in Semarang due to the reason that the defendant had terminated employment against the law.

In the lawsuit, the plaintiffs stated that at the end of February 2008, the defendants laid off their workers including the plaintiffs every Saturday in a week. A week later in March 2008 they were being laid off every Saturday and Monday or two days in turns and runs for approximately 2-3 weeks. In April 2008 it was changed into Saturday, Monday and Tuesday and workers including plaintiffs only paid $50 \%$ of their wages. Finally, on Monday 30 June 2008, the defendant suddenly held a sudden termination of employment for all of the workers without any prior notification on the grounds that the defendant experienced a loss of production activities. For this reason, the plaintiff asked the council of the judges that the termination of employment declared null and void and ordered the defendant to reinstate the plaintiff.

In his reply, the defendant stated that since the global economic crisis and the global financial crisis had hit especially in European countries since March 
2008 and reached its peak in September 2008 where CV. Reka Furindo as a defendant was absolutely dependent on the conditions of the European economy that impacted due to the European consumers unilaterally and simultaneously stopped the order of goods from the defendant. The Defendant has tried to be able to maintain the stable condition of the company, however because the European market conditions did not recover the defendant was very forced to take a decision to terminate all workers, approximately 119 people including the plaintiffs had previously held discussions between the defendant and his workers. For this reason, the defendant in his reply asked the council of judges to decline the plaintiff's claim. In its decision, the councill of judges of the Industrial Relations Court of Semarang which proceed the case read out on 13January 2009, stated that in accordance with Article 164 of Law No. 13 of 2003, employers can terminate employment if:

a. An employer can terminate the employment of a worker/laborer because of an enterprise closure that is caused by the enterprise experiencing losses continuously over 2 (two) years, or an act of God (force majeur), with the stipulations that the worker/laborer has the right to severance pay as much as 1 (one) time the stipulations in Article 156, clause (2), employment appreciation pay 1 (one) time the stipulations in Article 156, clause (3), and right replacement pay according to the stipulations in Article 156, clause (4).

b. Enterprise losses, in the same manner as is meant in clause (1), must be proven with financial report for the last 2 (two) years that have been audited by a public accountant.

The council of judges considered that all the evidence submitted by the defendant could not be found at all, or explained that the economic condition of the company fulfilled the above conditions so that the termination of employment by the defendant was invalid. Therefore, in its decision, the council of judges stated that the termination of employment was against the law and therefore the defendant was convicted of reinstating the plaintiffs.

One more example, in the case of Industrial Relations Disputes Number 34/G/2009/PHI.SMG, the Plaintiff on behalf of Susilo Dwi Utomo who was a worker at PT. Belgindo Raya based in Jl. Brigadier General S. Sudiarto Km 11.5 No. 773 Semarang sued PT. Belgindo Raya as the defendant to the Industrial Relations Court of Semarang on 26 February 2009. The plaintiff in his lawsuit stated that the defendant issued a letter of termination of employment to the plaintiff which contained that the worker was no longer allowed to work for the defendant. The reason was because the plaintiff considered giving false reason to absence of the work, such as went out of town but submitting the reason for 
getting sick and further the plaintiff doing a double job as a Wiyata Bhakti teacher in Soka I Brambang Elementary School, Karangawen District, Demak Regency.

The Plaintiff explained that the termination of employment by the defendant on the grounds that the plaintiff gave a false statement with permission to get sick was incorrect because the plaintiff was really sick. This information was proven by a doctor's written explanation. Meanwhile, the reason for the defendant's termination of employment with the plaintiff by reason of the plaintiff's dual work as a Wiyata Bhakti teacher in Soka I Brambang Elementary School in Karangawen Sub-District Demak Regency cannot be justified because it is the right of every person or citizen based on Article 27 paragraph (2) Jo Article 28-A Jo. Article 28D paragraph (2) of the 1945 Constitution. The Plaintiff also stated in his lawsuit that the plaintiff had never received the first, second and third warning letters from the defendant.

The defendant in his reply said that the defendant had indeed made a termination of the employment of the plaintiff because the disciplinary action that had been carried out by the plaintiff and the violation had met the terms and conditions of Article 158 paragraph (1) letter b of Law No. 13 of 2003 which can be terminated. The defendant stated that the plaintiff had indeed given false statement and was deliberately falsified. This was concluded by the defendant based on an investigation conducted on 5 December 2008. During the investigation, the defendant met directly with the plaintiff's biological mother who told what the plaintiff had done when he was absence of work with a doctor's written explanation. The plaintiff was apparently not sick because he could go out of town with his family to attend his brother's wedding and on 5 December 2008 he taught at the Soka I Brambang Elementary School in Karangawen District, Demak Regency.

The Council of Judges in its verdict read out on 19 May 2009 stated that the plaintiff was terminated by the defendant because the plaintiff had taken disciplinary action such as giving false statement and deliberately falsifying it. The council of judges stated that Article 161 of Law No. 13 of 2003 stipulates that the employer can terminate employment if the worker/laborer violates the provisions stipulated in the employment agreement, Company Regulation or Collective Labor Agreement. This provsion required the condition after the worker/laborer concerned is given the first, second and third warning letters in sequence. Based on the evidence submitted by the defendant, the warning letter was not found. The council of judges also stated that Article 158 of Law No. 13 of 2003 which regulates termination of employment due to serious mistakes made by workers who have no binding legal force based on the Decision of the Constitutional Court Number 012/PUU-I/2003. Based on these considerations, 
the council of judges further stated that the defendant had terminated employment was not in accordance with the law. Therefore, the defendant was sentenced to reinstate the plaintiff back to the work in PT. Belgindo Raya.

\section{The Decision To Reinstate The Worker/Laborer Is Difficult To Carry Out}

However, it turns out that the decisions above were not carried out because the employer did not want to reinstate workers/laborers who had been terminated. This is probably due to employers no longer compatible to work with workers/ laborers, such as the stigma that worker/laborer considered lazy to work. This condition can be understood considering that working relationship are basically relationships to cooperate with each other, even though the objective of each party are different. Employers depend on themselves to workers/laborers to conduct the work in order to gain profits, while the workers/laborers depend on themselves to certain conditions to employers to be paid (Giusappe Casale, 2011: 5). Clearly, in order to achieve the goals, mutual trust is necessary to be able to cooperate well.

Another possible reason to reinstate is difficult for the employer because the position left by the worker/laborer during the termination of the employment until the issuance of a court decision with legal force remains had filled by other workers or new workers. Generally, under the ongoing process of terminating employment through the court, the employer would suspend the worker/laborer concerned. This suspension is given by employer to workers/laborer under the reason to avoid serious risks in the workplace, for example workers/laborers concerned slow down in his/her work or workers/laborers influence other workers by giving negative views about the company. On the other hand, this suspension causes the position left by workers/laborers was empty. Furthermore, in other example the results of the work are very influential for other jobs if not carried out continuously. Therefore, employers do not want to take the risk of worse conditions, as for the position was filled by other workers/laborers or new workers/laborers in temporary.

The decision to reinstate may also be difficult to implement if the return of the worker/laborer to the previous position will lead to negative prejudice to the worker/laborer, i.e. the employer rated that they could no longer cooperate with the workers/laborers due to the indisciplinary actions of the workers/ laborers. Employers are worried that if they reinstate workers/laborers in the company, even if placed in the previous, the workers/laborers will act improperly. Such actions, for example, damage the company's property, slow down the performance of work which reduces the productivity of the company, influences other workers/laborers to make a negative perception of employers, and so on. 
Certainly, this situation is potential to occur which is not desired by employers in maintaining and increasing productivity of the company to advance the value of their investments.

The reinstate of worker /laborers to the previous position is not appropriate to be given if it will risk on the working relationship between workers/laborers concerned with other workers/laborers in the workplace. For example, workers/ laborers who were reinstate in previous positions were known by other workers/ laborers as a worker/laborer who found it difficult to cooperate and sometimes carry out intimidating actions against other workers/laborers. Therefore, the reinstate of workers/laborers to previous position will be highly not expected by other workers/laborers. Certainly, this will be considered as a condition that can hindered the productivity.

Finally, the situation to reinstate the workers/laborers to the previous position will not be appropriate if the worker/laborer concerned has a confidential capacity for company secrets because the employer has no longer trusts the workers/ laborers concerned. For example, workers who are reinstated to their previous position positions as the Finance Manager knows the company's very confidential financial data. Employers are worried that if the worker /laborer concerned is reinstated, he/she can divulge confidential company data.

\section{E. CLOSING}

\section{Conclusion}

Based on the discussion above, it can be concluded that there are circumstances that need to be considered by the Industrial Relations Court judges in making decisions of reinstated workers/laborers in cases of employment termination disputes between employers and workers/laborers, including:

a. The return of workers/laborers to previous work is not appropriate given if this will lead to an inharmonious relationship between employers and workers/laborers;

b. The return of workers/laborers to the previous position is not appropriate given if the position left has been filled by other workers/laborers;

c. The return of the worker/laborer to the previous position is not appropriate given if the decision will cause a prejudice to the worker/laborer, for example the employer rated that he/she is no longer trusted to cooperate with workers/ laborers in the workplace due to the indisciplinary actions;

d. The return of workers/laborers to the previous position is not appropriate if the action will make a negative impact on the working relationship between 
workers/laborers concerned and other workers/laborers in the workplace; and /or

e. The return of workers/laborers to previous position is not appropriate given if the workers/laborers concerned have a confidential capacity for company secrets because the employer no longer trusts the workers/laborers concerned.

\section{Suggestions}

The Industrial Relations Court Judge in making a decision regarding the termination of a employment dispute that instructs employers to reinstate workers does not only consider the juridical aspects of whether or not the employment is terminated by the employer, but also needs to consider other aspects related to risks if the working relationship continue. If the indications of these risks is strong, then the decision to reinstate workers should be given an alternative if the decision is not carried out by the employer, i.e. in the form of a compensation number that must be given to workers/laborers.

\section{BIBLIOGRAPHY:}

\section{Books:}

Adrian Sutedi, 2009, Hukum Perburuhan (Labour Law), Sinar Grafika: Jakarta.

Bob Hepple, 1986, The Making of Labour Law in Europe: a comparative study of nine countries up to 1945, Mansel Publishing Limited: London and New York,.

Edi Sutrisno Sidabutar, 2007, Pedoman Penyelesaian PHK (Settlement Guidelines of Breaking Labor Relations), Praninta Offset: Jakarta.

Giuseppe Casale, 2011, The Employment Relationship: A Comparative Overview, Hart Publishing: Oxford,

Kenneth G. Dau-Schmidt et. al., 2009, Labor and Employment Law and Economics, Edward Elgar publishing: Cheltenham,.

Lalu Husni, 2008, Pengantar Hukum Ketenagakerjaan Indonesia (Introduction of The Indonesian Labour Law), Edisi Revisi, PT Raja Grafindo Persada: Jakarta, .

Richard N. Block et al., 2004, The Economic Dimension of the Employment Relationship, dalam Jacqueline A. et. al. (Editors), The Employment Relationship: Examining Psychological and Contextual Perspectives, Oxford University Press: Oxford,. 


\section{Journals:}

Budi Santoso dan Ratih Dheviana, 'Eksistensi Asas Kebebasan Berkontrak dalam Perjanjian Kerja' (2012) 6 (3) Arena Hukum.

\section{Regulations:}

Law Number 13 of 2003 on The Labour (State Gazette of The Republic of Indonesia Number 39 of 2003).

Law Number 2 of 2004 on The Dispute Settlement of Industrial Relations (State Gazette of The Republic of Indonesia Number 6 of 2004)

ILO Declaration on The Purposes and Aim of The International Labour Organization 1944

Supreme Court Decision Number 13 PK/PHI/2007.

Supreme Court Decision Number 051 PK/Pdt.Sus/2009.

Supreme Court Decision Number 701 K/Pdt.Sus/2009.

Industrial Relations Court at Semarang District Court Decision Number 33/G/2009/ PHI.SMG.

\section{Internet:}

.Hukumonline, Putusan Mahkamah Agung Membuat Karyawan Pertamina Bingung, http://www.hukumonline.com/berita/baca/hol18689/putusan-mahkamahagung-membuat-karyawan-pertamina-bingung (diakses pada tanggal 1 Maret 2016). 